\title{
The evolution of Late Medieval Seigniorial Residences in the Basque Country: analysis of a Pre-Renaissance Palace: the Guevara Palace in Segura (Gipuzkoa, Spain)
}

\author{
D. Luengas-Carreño, M. Crespo de Antonio \& S. Sánchez-Beitia \\ Higher Technical School of Architecture, UPV/EHU, Spain
}

\begin{abstract}
The Late Medieval Seigniorial Residence is one of the most relevant elements of the built heritage of the Basque Country (Spain). The architectural form of these buildings evolved from the defensive Tower Houses of the fourteenth and fifteenth centuries to the early Renaissance Palaces of the sixteenth century, due to the decrease of the intensity of medieval conflicts. Analysis carried out in a previous project, which has generated an inventory of Late Medieval Seigniorial Residences in the Basque Country, has identified four main evolutionary phases: single Tower Houses, Tower Houses transformed into Palaces, Tower Houses with annexed Palaces and Pre-Renaissance Palaces. This paper aims to analyze the last evolution phase of this building-typology, by the study of a singular case: the Guevara Palace in Segura (Gipuzkoa, Spain). The building has been investigated from different perspectives through historical documentary analysis, historical constructive analysis and structural pathologies analysis. The research has identified six different building periods in the Guevara Palace. Although the building suffered main transformations throughout the nineteenth century, it has kept many of its original architectural features, such as the main façade sandstone masonry walls, a major part of the timber structure or Catholic Kings Style ornamentation details; a wide range of architectural elements that show the characteristic features of Pre-Renaissance Palaces. This paper is part of a broader research project which aims to develop a cataloguing model for Late Medieval Seigniorial Residences of the Basque Country.

Keywords: heritage masonry buildings, Seigniorial Residences, Late Medieval Palaces, historical constructive analysis, structural pathologies analysis.
\end{abstract}




\section{Introduction}

In the Medieval Age, Basque rural nobility was organized into pyramid-type structure lineages, which were led by lineage chiefs, also known as "The Elders". In the fourteenth century, the late medieval economic crisis and the rise of the royal foundation villages caused the decrease of the economic incomes of these families, and gave rise to several armed conflicts between neighboring lineages. Gradually, these struggles escalated into an open warfare between two partialities: the Gamboa faction and the Oñaz faction [1]. For this reason, as in other parts of Europe [2,3], The Elders began to build defensive residences: The single Tower Houses. These parallelepiped masonry buildings were the first evolutional phase of Late Medieval Seigniorial Residence typology and they served to control the geostrategic points of the territory (bridges, roads, mills, forests, chapels, village gates, etc.).

The bloodiest period of the war was mid-fifteenth century, when the fighting reached several royal foundation villages, such as Mondragon, which was burnt in 1448. As a result of this escalation of violence, the Castilian King decided to punish The Elders, demolishing their Tower Houses and prohibiting the construction of new military buildings $[4,5]$.

Under those circumstances, in the late fifteenth century, Late Medieval Seigniorial Residences had to evolve to "more domestic" forms. A significant number of lineages restored what was left of their Tower Houses, using palatial architectural elements, reducing the height of the buildings and opening new Catholic Kings Style ornamented windows and doorways. Other nobles preferred to build annexed Palaces to their Tower Houses, becoming more luminous and better equipped new residential spaces. This trend soon gave way to a new residential model: The Pre-Renaissance Palaces of the early sixteenth, the last evolutional phase of Late Medieval Seigniorial Residence typology [6].

The Guevara Palace is placed in the royal foundation village of Segura (Gipuzkoa, Spain), in the centre of the main street and next to one of the village gates. This representative case of Pre-Renaissance Palace covers a surface area of three medieval plots. Despite the building is arranged on only two floors (stables/warehouse and main floor), originally had two side towers, reminiscent of primitive defensive Tower Houses. The main façades, which are built with sandstone masonry pieces, preserve some Catholic Kings Style elements, such as ogee windows, helmets without mantling, gargoyles or lines of stone "balls". These walls are structured according to the Pre-Renaissance Palace model: a large round arched doorway, some arrowslit shape windows in the ground floor façade and a gallery of gothic windows in the main hall. The rear facade is built with poor masonry, without significant architectural elements. The horizontal timber structure rests directly on the masonry walls, which are thinner on the top floor. Taking advantage of the uneven ground, the northern part of the building has a mezzanine and, in this case, the timber beams are held up by stone brackets. The roof structure is formed by King post trusses. Nowadays, the palace is divided into three different properties, which has hindered to maintain and to preserve the palace homogeneously. 


\section{Methodology}

The building was investigated through historical documentary analysis, historical constructive analysis and structural pathologies analysis.

In the historical documentary analysis, the documents were searched in the following archives: Municipal Archive of Segura, Historical Provincial Archive of Gipuzkoa, Historical Protocol Archive of Gipuzkoa, General Archive of Gipuzkoa, Archive of the Royal Chancellery of Valladolid, Historical State Archive of Spain and General Archive of Simancas. Historical pictures, maps and photographs were obtained in the following digital repositories: Digital repository of the Gipuzkoa Council, Basque Digital Library, GureGipuzkoa repository, Digital Periodical Library and EMD repository. The texts were edited using guidelines of the International Commission of Diplomatic [7].

In the historical constructive analysis, the stratigraphic study of the façades was carried out using the Harris method [8]. This method is based on the creation of different temporal sequences, which are organized through a diagram called Harris Matrix. The matrix reflects the relative position and contacts of observable stratigraphic units. Complementarily, a detailed study of the walls was performed; indicating different materials, building periods and alterations, such as not original walls or walled windows and doorways. A PCE-TC 3 thermal imaging camera was used to detect hidden items.

In the structural pathologies analysis, the timber structure and masonry walls were analyzed searching for biotic/abiotic origin and structural origin damages. A PCE-TC 3 thermal imaging camera was used to locate affected areas. Additionally, moisture content of wood elements was measured with a BM15 moisture indicator and walls moisture was measured with BM31 moisture indicator. The representation and classification of the damages were developed following the guidelines recommended by Ramón-Cueto et al. [9].

\section{Analysis}

\subsection{Historical documentary analysis}

More than fifty historical documents were discovered during the research, most of them in the Municipal Archive of Segura, where architectural drawings of 1880 were located. The oldest picture of the palace dates from 1915, and it was discovered in the General Archive of Gipuzkoa. The analysis of historical documentation revealed six main building periods.

\subsubsection{Period 1 (1498-1613): construction of the palace}

The first owner on record of the palace was Nicolas de Guevara, who started to build it in the late fifteenth century, possibly after the fire of 1492, which destroyed almost all constructions of Segura. The first time this building is historically mentioned was in 1504, in the testament of Nicolas de Guevara. According to this document, the Guevara Palace was built using stones of the destroyed Tower House of Bachiller Larrastegui, the brother of Nicolas. 
Juan de Guevara, the successor of Nicolas, finished the construction of the palace in the early sixteenth century. In accordance with his testament of 1543, Juan built mezzanines, spiral staircase and fireplaces. The first mention of the "missing" side towers is from the Majorat confirmation of Diego de Guevara (the son of Juan) of 1543, where a brief description of the palace was reported.

\subsubsection{Period 2 (1613-1853): abandonment of the palace}

In consonance with the documents of this period, Mariana Bonifaz Ladrón de Cegama, the owner of the Guevara Palace in the early seventeenth, abandoned the palace and moved to Madrid in 1613. In the next decades, the building was leased to families with fewer economic resources, causing the deterioration of the architectural elements, due to the lack of proper maintenance. In this sense, documents of Municipal Archive of Segura revealed that the Guevara Palace was used as a hostel in the eighteenth and nineteenth centuries.

According to a text of 1815, the palace was in an advanced state of deterioration in the early nineteenth. As a result, there was even a collapse of one of its walls. Another document of the Archive of Segura of 1829 describes how the two side towers had serious damages, being a risk for pedestrians.

\subsubsection{Period 3 (1853-1888): removal of the two side towers top floor}

On April 18 of 1853, the council decided to demolish the top of the towers. One year later, the palace was separated from the Majorat of the Guevara family, when Ignacio Martin Diez bought it. In the next decades, it was rented by different families, which certainly opened new voids in the façades, in order to adapt the rooms to their needs. Lease documents also suggest that the palace lost surface area in the southern part in that period, where a new building was raised.

\subsubsection{Period 4 (1888-1915): subdivision into three different properties}

On May 6 of 1888, the Guevara Palace was purchased by Esteban Zurbano, who subdivided it into three different lots. In the subdivision works, new walls were raised and some elements were bricked up, as evidenced by the architectural drawings of 1888 (fig. 1, where the southern subdivision is painted in red, the central subdivision appears in white and the northern subdivision is in yellow).
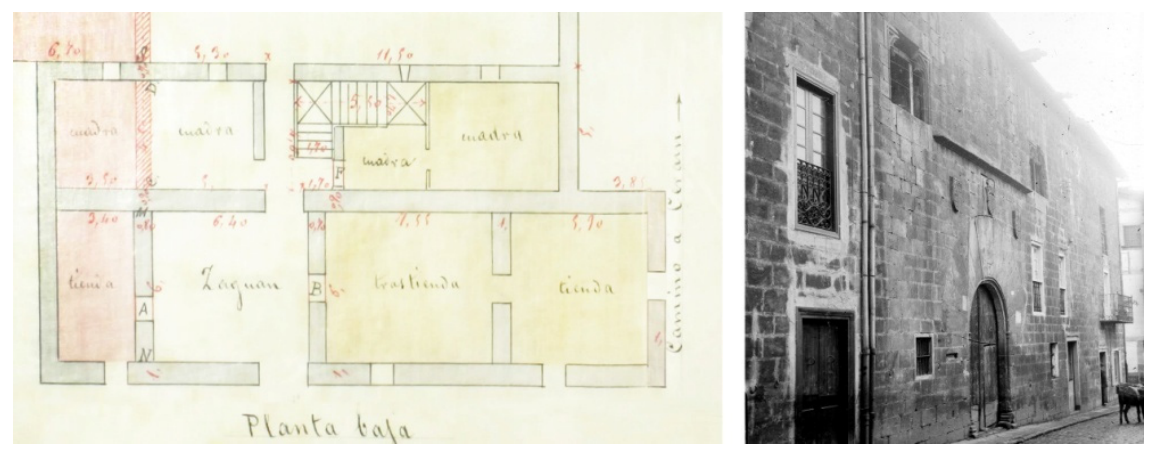

Figure 1: Subdivision drawings of 1888 and a picture from 1915. 
Another important document of this period is a photograph of 1915, obtained in the General Archive of Gipuzkoa (fig. 1). Taking into consideration the differences between this photograph and the architectural drawings of 1888, main façade was substantially transformed in this period of time.

\subsubsection{Period 5 (1915-1984): some interior works}

On July 17 of 1984, the Guevara Palace was declared Historic Artistic Monument by the Basque Government. For this reason, government technicians carried out an inspection of the building, achieving an extensive photo report of the property. In consonance with these pictures, new voids were opened in the three façades. Furthermore, all subdivisions of the palace were refurbished internally for 1984, since the photographs of this year show an almost identical interior decoration and distribution to the current one.

\subsubsection{Period 6 (1984-2014): refurbishment of the central subdivision}

In accordance with a demolition project, the southern part of the building belonged to the adjoining property in 1987. This explains why this subdivision has different floor to floor heights in relation to the rest of the building.

In 1994, central subdivision of the palace was refurbished thanks to a financial aid of the Provincial council of Gipuzkoa. Timber structure was strengthened, central roof was replaced and trefoiled windows were repaired. The last architectural intervention was made in 2008, when the rear garden was renovated and some annexed constructions were demolished.

\subsection{Historical constructive analysis}

The information and building periods obtained in the previous historical documentary analysis were used to guide historical constructive analysis.

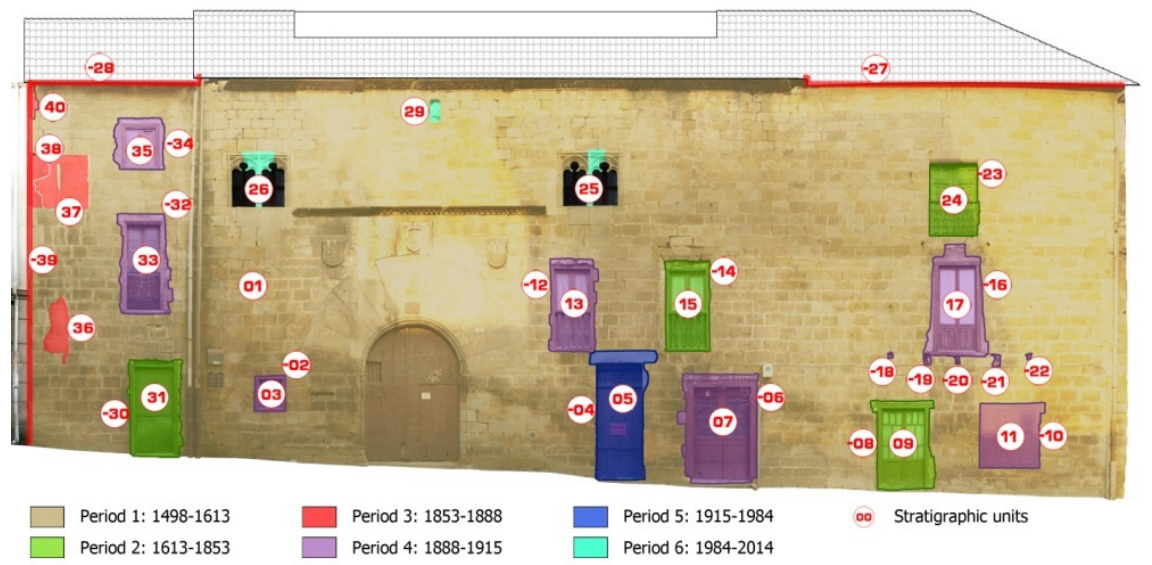

Figure 2: Stratigraphic study of the main façade. 


\subsubsection{Period 1 (1498-1613): construction of the palace}

The original main walls of the building were made in sandstone ashlars, which were distinguished by their great thickness and bounding (fig. 2). The original walls have discontinuities in the southern part of the building (left side of fig. 3) and some of interior rooms conserve their original round arched doorways.

Thermal imaging camera revealed the bounding of a significant number of plaster covered walls and architectural elements. The research discovered an ogee-headed arrowslit in the ground floor (fig. 2, stratigraphic unit 36), remains of three double trefoiled windows in the main floor (fig. 2, stratigraphic units 24 and 37), a small ogee-headed window at the top of the main façade (fig. 2, stratigraphic unit 29), and four round arched doors in the rooms (fig. 3).
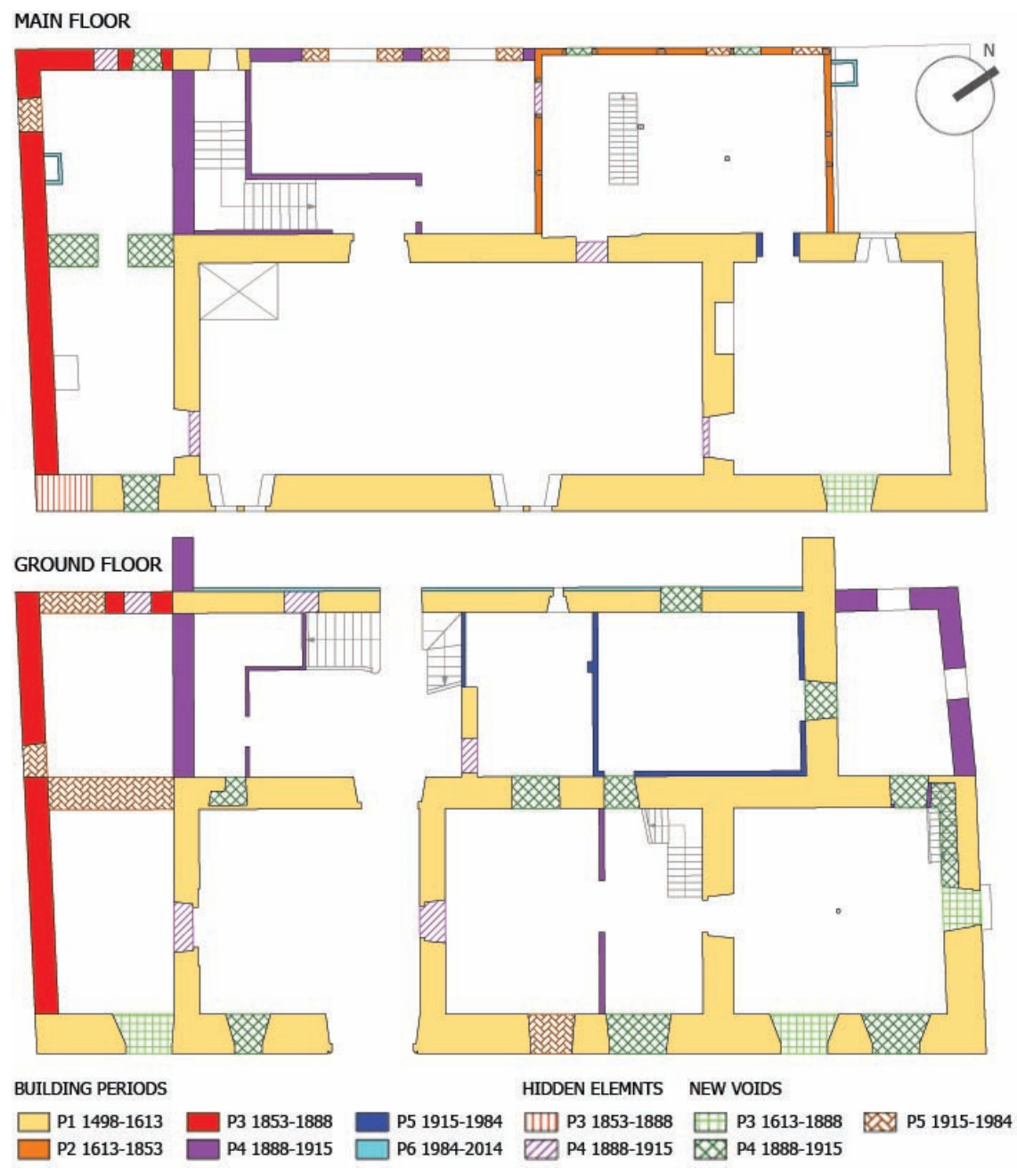

Figure 3: Building periods of the main and ground floors. 


\subsubsection{Period 2 (1613-1853): abandonment of the palace}

As mentioned in the previous analysis, the Guevara family abandoned the palace in the early sixteenth, and it was rented to peasant families, who used it as an inn. The renters raised new walls and built more rooms both in the mezzanine and in the main floor (right side of fig. 3), needing to open new windows in the main façade (fig. 2, stratigraphic units 9, 15, 24 and 31). In addition, timber framing enclosure was built in the northern part of the rear façade, which replaced a previous one destroyed in a fire, as evidenced by remnants in the adjacent walls.

\subsubsection{Period 3 (1853-1888): removal of the two side towers top floor}

The most relevant remains of this period are the cuts produced by the demolition of the side towers (fig. 2, stratigraphic units 39, 27 and 28). During this refurbishing work, a double trefoiled window and an ogee-headed arrowslit were bricked up (fig. 2, stratigraphic units 36 and 37). In the southern part, a new poor masonry rear facade and dividing wall were built (fig. 3).

\subsubsection{Period 4 (1888-1915): subdivision into three different properties}

According to the architectural drawings of 1888, the most important transformation was carried out in this period of time. During this refurbishing, an annexed construction was built and a basement was excavated in the northern part. A new masonry wall was also raised between the southern and central subdivisions and a timber framing enclosure was built in the central part of the rear façade (fig. 3). In this period of time, fourteen new voids were opened in the façades, seven new inside passages were built and eight voids were bricked up.

The thermal imaging camera revealed a significant number of hidden architectural elements, such as rear façade windows (fig. 4), which appear in the drawings of 1888. Additionally, this camera was used to distinguish between the paste covered original and not original walls, owing to the difference of emissivity of the materials of both types of walls.

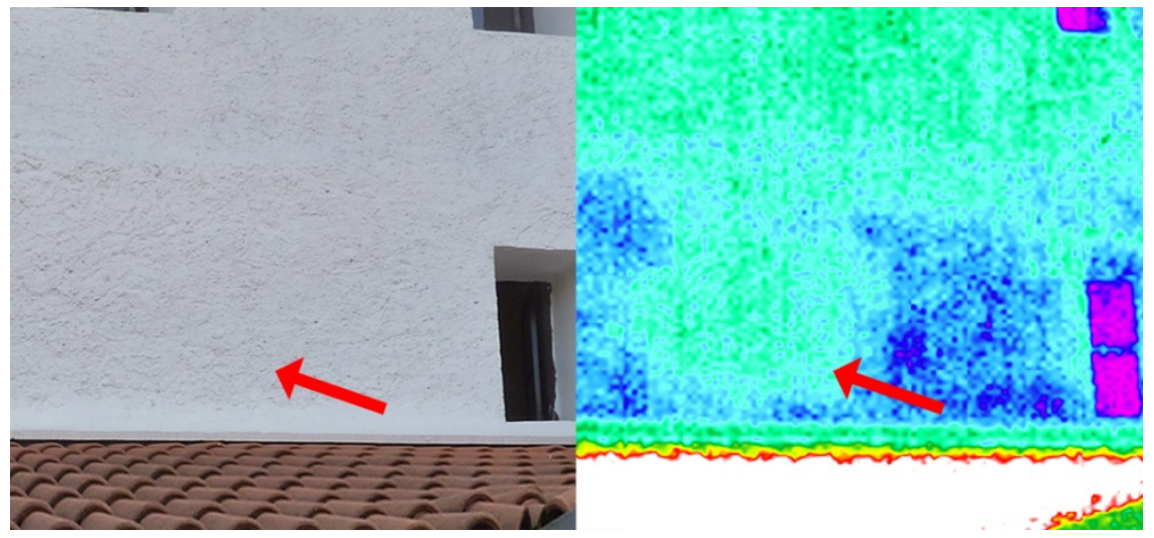

Figure 4: Hidden window in the rear façade. 


\subsubsection{Period 5 (1915-1984): some interior works}

In this building period not many changes were made. In the back area, three new brick walls were raised to build a new kitchen. In the southern subdivision, new voids were opened in the dividing wall, a masonry inner wall was demolished and some windows were bricked up (fig. 3).

\subsubsection{Period 6 (1984-2014): refurbishment of the central subdivision}

During the refurbishment of the central subdivision, some brick walls were erected to create new rooms (fig. 3). Additionally, two double trefoiled windows and a small ogee-headed window were repaired (fig. 2, units 25, 26 and 29).

\subsection{Structural pathologies analysis}

The structural pathologies analysis revealed three large width cracks at the top of the main façade (fig. 5, units 1-3). The research determined that these cracks were stable and they did not pose a risk to the stability of the building. In this sense, the analysis of these elements established that the cause of these cracks was the great weight of the demolished side towers and their improper design (the primitive Tower Houses had thicker walls and they were structurally more stable than new ones). The study also disclosed seven small width cracks. Most of them were generated when new voids were opened, forming discharging arcs caused by the wrong dimensioning of the lintels of windows and doors (fig. 5, units 4-8). The other cracks were caused by the rupture of three original window lintels (fig. 5, units 9-11), also due to the weight of the towers.

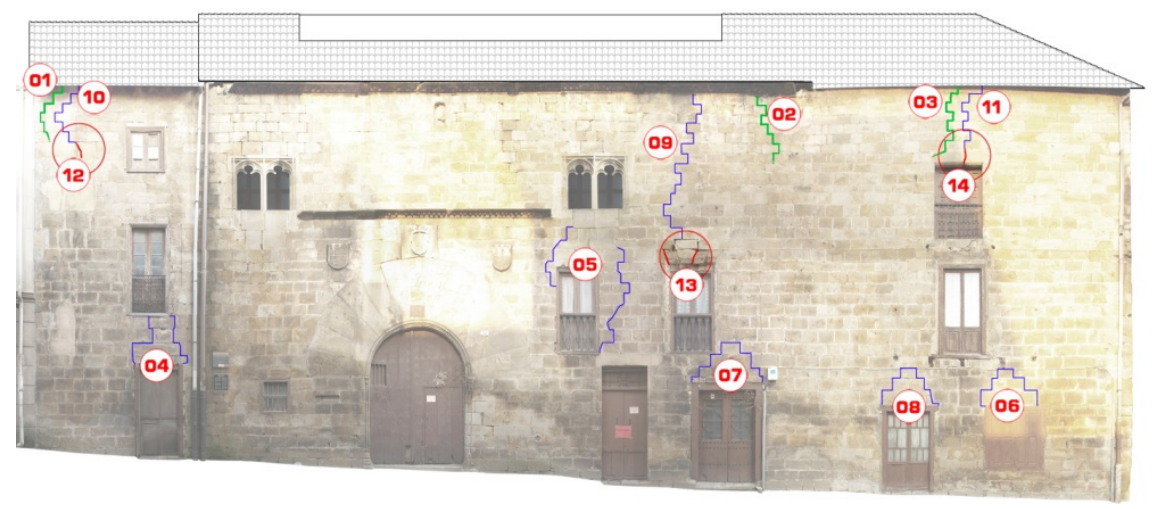

Figure 5: Cracks in the main façade.

In the inner rooms, a large width crack highlighted in the toilets of mezzanine (fig. 6). The analysis revealed that this damage was located in the original stairwell hole. During the subdivision works of 1888, this hole was covered using non-structural panels (wooden doors), causing a great deformation and displacement of the floor. 

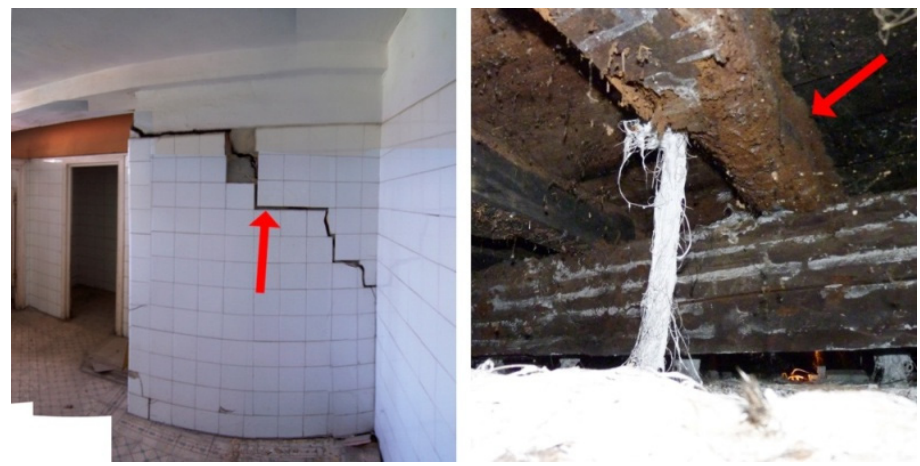

Figure 6: Crack in the toilets of the mezzanine and a woodworm damaged beam.

The thermal imaging camera was used to provide an overall view of moisture of the palace. The southern roof was the most affected area by this pathology, owing to the lack of waterproofing. This also caused the appearance of woodworm and fungal rot in timber elements of the three floors in this subdivision (fig. 7). Other areas affected by moisture were the northern roof and the basement, in which the timber structure began to collapse partially. Furthermore, the analysis revealed that four timber beams of the kitchen were serious damaged by Anobiidae (fig. 6). In the annexed construction, moisture also caused the appearance of efflorescence on the concrete roof (fig. 7, right top side of the first floor).

In the main and side façades, ashlar sandstone walls were worn due to the continued impact of raindrops and wind, especially at the bottom of the façades, where there were areas damaged by microorganisms and vegetation. The main façade was also affected by presence of black crusts in the cornices, owing to the heavy traffic of the street, which caused the sedimentation of air pollution particles in the last decades.

\section{Conclusion}

The historical documentary analysis was a useful tool to understand the alterations of the Guevara Palace over its history, produced by the changes in use and a subdivision process. In this sense, the study found six main building periods, which served to structure the historical constructive analysis. Complementarily, historical documentary analysis was effective to determine the origin of some of the pathologies, such as main façade's large width cracks, which were originated due to the great weight of the demolished towers.

The case study is an example of how noble families abandoned their Late Medieval Seigniorial Residences to move to big cities in the seventeenth century, seeking to increase their power. Interestingly, the Guevara Palace, the home of 

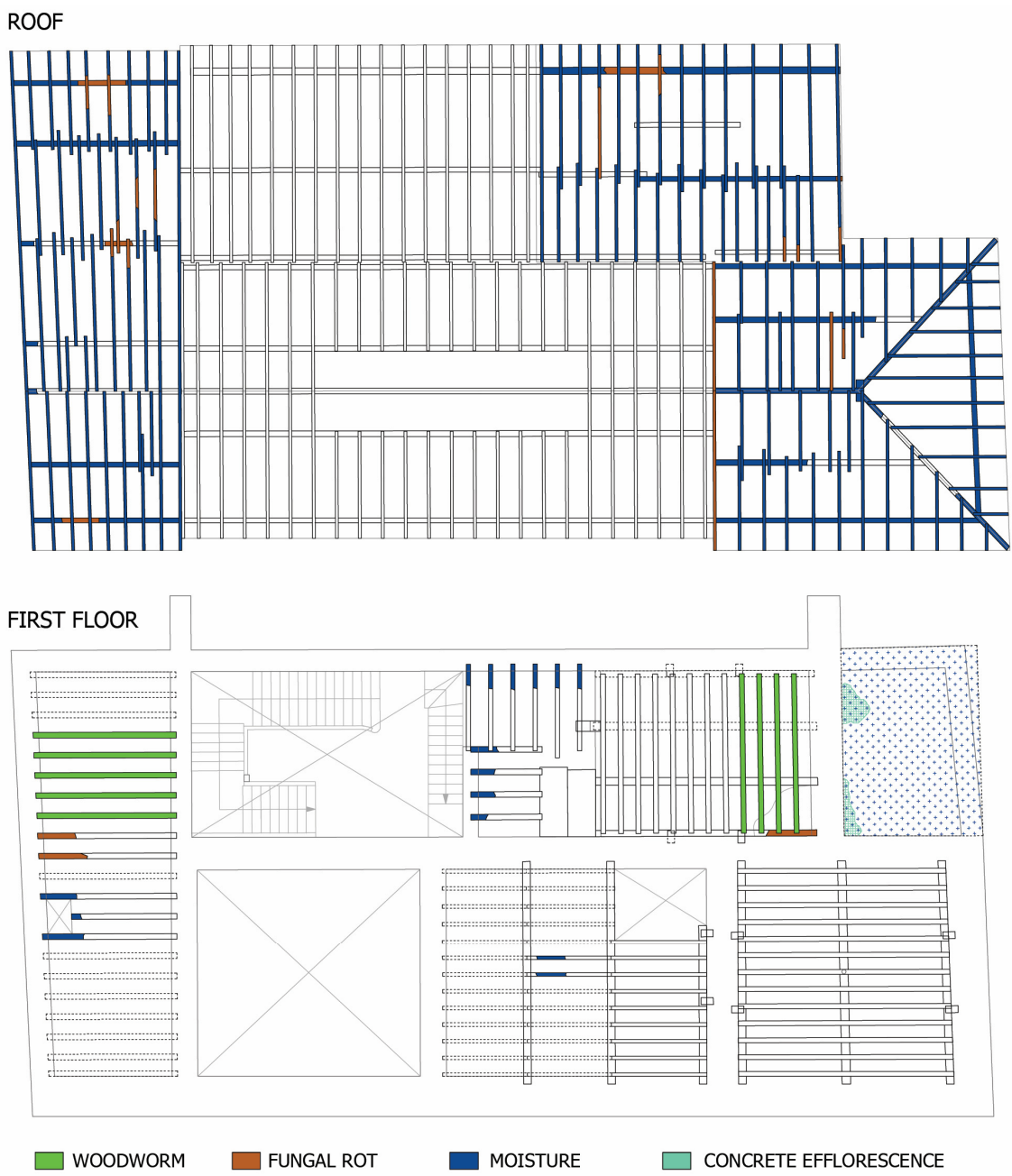

Figure 7: Pathologies of the structure.

the most important family of Segura in the sixteenth century, was transformed into an inn in a relatively short period of time, refurbishing the interior rooms and opening most current façade voids, as in other Late Medieval Seigniorial Residences studied. The analysis of the subdivision process revealed as walls, windows and doors were bricked up in the nineteenth century, drawing architectural plans and detailing the materials used.

The historical constructive analysis was helpful to determine the architectural original elements and to define a formal image of the primitive construction: a large round arched doorway, some arrowslit form windows discovered in the ground floor and a gallery of five trefoiled windows of two lights in the main hall (the research discovered three of them). Consequently, these results 
represented a major step toward understanding the Pre-Renaissance Palaces and its singular elements. Additionally, the study was useful to rule out the hypothesis that the palace was built on the remains of a defensive Tower House, because of the detailed analysis of architectural elements disclosed no previous constructions to mentioned building periods.

The structural pathologies analysis served to get a general idea of the common pathologies of Late Medieval Seigniorial Residences, such as moisture content, xylophagous insects, fungal rot, wear of stone material, microorganisms, vegetation and cracks. For example, the discharging arc shape small width cracks found in the Guevara Palace also appear in other cases studied belonging to this architectural typology, caused by the opening of new windows and doors and poorly dimensioned lintels.

The research was also appropriate for the assessment of the state of preservation of the building. In this sense, the structural pathologies analysis revealed that the southern subdivision was the worst preserved area, being greatly affected by moisture, fungal rot and woodworm in its three floors and roof. The central subdivision was the best conserved area, owing to the refurbished work of 1994, in which the timber structure was strengthened and the roof was changed. In the northern subdivision, the most severe damage was located in the main floor, where water infiltration and misguided repairs were harming the timber structure. In the kitchen roof were discovered four timber beams affected by woodworm (Anobiidae).

This paper is a contribution toward understanding the architectural form of Late Medieval Seigniorial Residences in the Basque Country, through the study of a singular case of the last evolution phase of this building-typology (PreRenaissance Palaces). The study is part of a broader research project which aims to develop a cataloguing model for Late Medieval Seigniorial Residences of the Basque Country. Further research is needed to determine the evolution of the construction system of this building-typology by the study of other singular cases of the four main evolutionary phases (single Tower Houses, Tower Houses transformed in Palaces, Tower Houses with annexed Palaces and PreRenaissance Palaces).

\section{Acknowledgements}

This paper was supported by a research training grant from the Research Vicerrectorate of the University of the Basque Country UPV/EHU. The researchers also want to acknowledge the assistance provided by the staff and students of the Master in Refurbishment, Restoration and Integral Management of Historical Constructions of the University of the Basque Country.

\section{References}

[1] González Cembellín, J. M., Torres de las Encartaciones, Diputación Foral de Bizkaia: Bilbao, 2004. 
[2] Sherlock, R., Cross-Cultural Occurrences of Mutations in Tower House Architecture: Evidence for Cultural Homogeneity in Late Medieval Ireland?. The Journal of Irish Archaeology, 15, pp. 73-91, 2006.

[3] Cruden, S., The Scottish Castle. Nelson: Edinburgh, 1960.

[4] Orella Unzué, J.L., Estévez Rodríguez, X., Casas-torre y palacios de Gipuzkoa, Colegio de Aparejadores de Gipuzkoa: San Sebastián, 1996.

[5] Portilla Vitoria, M.J., Torres y casas fuertes en Alava, Caja de Ahorros Municipal: Vitoria, 1978.

[6] Luengas-Carreño, D., Sanchez-Beitia, S., Late-medieval Seigniorial Residences in the Basque Country: Analysis of the evolution of construction system and its singular elements. Proc. of the Rehabend 2014, Universidad de Cantabria: Santander, pp. 110-117, 2014.

[7] International Commission of Diplomatic, Folia Caesaraugustana I, Fernando el Católico Institution: Zaragoza, 1984.

[8] Harris, E.C., Principles of Archaeological Stratigraphy, Elsevier: London \& New York, 1989.

[9] Ramón-Cueto, G., Basterra, L.A., Acuña, L., Casado, M., López, G., Codificación y representación de resultados en las inspecciones de estructuras de madera del patrimonio histórico orientadas a la elaboración del proyecto de restauración arquitectónico. II Jornadas de Investigación en Construcción. Instituto de Ciencias de la Construcción Eduardo Torroja: Madrid, 2008. 